\title{
On Heidegger's Sofa: Some Remarks on Psychotherapy from Historical and Philosophical Points of View
}

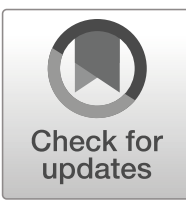

\author{
Timo Sampolahti ${ }^{1}$ (D) Aarno Laitila ${ }^{1}$
}

Received: 13 July 2019 /Revised: 26 August 2019 / Accepted: 20 September 2019 /

Published online: 4 December 2019

(C) The Author(s) 2019

\begin{abstract}
Our starting point in this article is that the question of the essence of psychotherapy has to some extent been neglected. Its medical context has strengthened the tendency to interpret psychotherapy in general from a technical and overtly rationalistic standpoint. Instead, we would underline the importance of the philosophical and historical roots of all psychotherapies. In our view, it is imperative to acknowledge the antirationalistic underpinnings that have always informed the discipline. We show how speculative mysticism and the late philosophy of Martin Heidegger have proved to be indispensable tools in setting psychotherapies in their philosophical and historical context. Robert Stolorow has also recently emphasised that Heidegger's philosophy in Time and Being can be used to both understand and develop thinking in psychotherapies. We find it surprising that Heidegger's late philosophy has not previously been considered a promising standpoint for theoretical research and show how Heidegger's concepts of twofold thinking and Gelassenheit are useful conceptual tools in understanding various dimensions of psychotherapies.
\end{abstract}

Keywords Psychotherapy · Heidegger · Wittgenstein. Freud · Intellectual History

"I cannot totally grasp, what all I am. Thus the mind is not large enough to contain itself: but where can that part of it be which it does not contain? Is it

Timo Sampolahti

timo.sampolahti@gmail.com

Aarno Laitila

aarno.laitila@jyu.fi

1 Department of Psychology, University of Jyväskylä, Jyväskylä, Finland 
outside itself or within? How can it not contain itself [How can there be any of itself that is not in itself?]."

Saint Augustine of Hippo AD 397-400.

\begin{abstract}
"Reason, for a long period, meant the activity of understanding and assimilating the eternal ideas, which were to function as goals for men. Today, on the contrary, it is not only the business but the essential work of reason to find means for the goals one adopts at any given time."

Max Horkheimer AD 1947.
\end{abstract}

\title{
1 Introduction
}

A friend told me the other day that his attitude to the polar night had changed. Earlier, when the days got shorter and nights longer and darker, he had found it horrifying. He tried to get more light into his home and he had started planning holidays abroad - as far south as possible. This happened every year. But then, a few years ago, something happened, just like that, spontaneously. Something he could not explain or understand at all. He found he could live with darkness, enjoyed it and welcomed it as a beloved friend.

We conceptualise the moment described above as comprising three components. The frst is the change itself, which is concretely observable; the second is the set of psychological and neurobiological processes underlying it; and the third is the issue of the nature or the essence of this deeply personal and intuitive experience. On the one hand, moments like the above can be described using the concept of the now moment, or moment of meeting, introduced into psychotherapy research by the Boston Change Process Study Group (Stern 1998). On the other hand, following William James (1902/ 2010) and Ludwig Wittgenstein (1921/1974), these experiences can be decribed as mystical. Romain Rolland, in turn, in his letter to Sigmund Freud, described such moments as experiences of oceanic feelings (Freud 1960).

The mystical as a part of human nature was a focus of interest for all three of the above-mentioned creative minds around the beginning of the twentieth century. For Freud, it was something he was impregnated with through his Hasidic roots and which he sought to rid himself of. For James, it was an undeniable part of the human predicament and being in the world. Wittgenstein understood that while the mystical as something that we cannot comprehend with language, it is at the same time selfevidently a part - and perhaps the most meaningful part - of human experience. Psychotherapy arose in a cultural landscape characterised by both flourishing in the natural sciences and a strong interest in the mystical layers of human subjective experience. To us, it seems natural and inevitable that in seeking to understand psychotherapy in its philosophical context, we have to acknowledge the mystical.

Having said this, it is clear that by the word mystical we are referring on the one hand to a certain quality of subjective experience and on the other to loosely defined attitudes or ways of being that resonate with this dimension of human experience. We 
are not proposing a new psychotherapeutic technique or theory; instead, we are pointing towards an ontological dimension that lies outside the rational construction of humankind and its situation in the world.

The term mystical/das Mystische does not necessarily refer to a religious world view. According to James (1902/2010) a mystical experience entails four aspects:

1. It is beyond language and rationality.

2. It has a cognitive dimension, that is more than just a feeling.

3. The experience is temporary. It is not a constant state of consciousness.

4. The role of the subject is passive. He does not try to induce the experience but simply allows him to become caught up it.

Mystical experiences do not tell us anything about the world as we see it. Reality is understandable from the logical and linguistic points of view. But as Wittgenstein eloquently stated, even if we knew every fact about the world, we would not have even started to understand life. The meaning of the world has to lie outside the world (Wittgenstein 1921/1974, 6.41). Instead of claiming anything about the world, mystical experiences are connected to an unmediated sense of meaningfulness, purposefulness and beauty.

Although that this last aspect could be said to be unimportant, to be too philosophical, to have irrelevant religious underpinnings or to be unnecessary or even harmful, we consider it to be of relevance in psychotherapy and psychotherapy research. We agree with Enckell and Enckell (2013), that the concept "moment of meeting" proposed by the Boston Change Process Study Group (BCPSG) links philosophical contemplation and empirical research in a promising way. It is an empirical and rational concept, but at the same time it presents, at least hypothetically, an opportunity to address the question about the possible mystical nature of such moments in psychotherapy. In this article, we underline the apophatic nucleus of subjective experiences in psychotherapy and propose an alternative way to analyse this mystical dimension from the standpoint of intellectual history.

Thus, we do not refer to the change itself but instead seek to capture, or at least point to, a mystical dimension that has been neglected in empirical psychotherapy research and that seems to explain empirical findings and behavioural and subjectively felt changes. We offer an auxiliary context of meaning to explain the bewildering fact that, after 60 years of modern psychotherapy research, it continues to be unclear why and how psychotherapy helps patients in emotional distress. We interpret this situation as indicating that perhaps this dilemma cannot be resolved only by doing better and more accurate empirical research. We believe that an alternative, hitherto neglected, dimension exists and in this article try to articulate what it might be. We claim that this dimension can be found in the intellectual heritage of the fin de siecle and that it helps to understand psychotherapy, its development and paradigms and the above-mentioned perplexities in empirical psychotherapy research.

It was was a period of rich and heterogenous cultural development impregnated with both decadence and optimism. It is somehow appropriate that this period of despair, decadence and hope of a new dawn fertilised the intellectual soil in which psychotherapy came into being. During this period, many genuinely new approaches to old problems were also invented. It was a time when analytic philosophy, psychoanalysis 
and expressive art started moulding the cultural landscape. In the arts, symbolism and expressive language opened up new opportunities to contemplate the human predicament (Schorske 1961/1981; Kandel 2012). As, along with the first world war, the cultural current increasingly distanced itself from romanticism, it paved the way for existentialism and modernism. In this article, we investigate what coming into being in this kind of cultural and intellectual enviroment meant for psychotherapy.

As is well known, meta-analyses have encountered difficulties in identifying the specific factors that could explain the results of psychotherapy (Wampold and Imel 2015). Nevertheless, such research continues to be carried out. We are aware that no consensus exists on whether the medical model continues to be the best metamodel for psychotherapy research or whether it should be replaced by a contextual or some other model. In both cases one question remains unanswered. This question concerns the antirationalistic and mystical dimension in psychotherapies. We consider this question of paramount importance and will try to explain why.

Theoretically, there are a few ways of investigating the question. First, we could analyse the concept from a philosophical point of view. Second, we could analyse the ways different psychotherapeutic schools have treated the question. And third, we could attempt to operationalise the concept and approach it empirically. Although each of these alternatives could be interesting and fruitful, we have chosen another path. To state it somewhat vaguely, we consider the question of psychotherapy from a humanistic point of view. In the present context it means that we will attempt to think psychotherapy in the context of human beings in general. Putting it in another way, we approach psychotherapy as a cultural artefact instead of considering it solely as a form of medical treatment. And because we define our task in this way, it is obvious that we find it crucially important to focus on the European intellectual landscape in which psychotherapy emerged, that is, the fin de siècle and its philosophical and intellectual dilemmas. Martin Heidegger together with Ludwig Wittgenstein, reformulated the intellectual dilemmas of the fin de siècle in a way that made them relevant to understanding of the inner dilemmas in psychotherapy. We know that Heidegger had been a figure of interest in psychotherapy and psychoanalysis on many earlier occasions: Ludwig Binswanger and Medard Boss approached psychoanalysis from Heidegger's standpoint and created Dasein analysis. Recently, the psychoanalyst and philosopher Robert Stolorow has re-introduced Heidegger to the psychotherapeutic audience. He sees in Heidegger's Being and time (1927) an opportunity for psychoanalysis to be reinterpreted and reformulated as a contextual, phenomenological and intersubjective project. From Stolorow's point of view, this would be a way of setting psychoanalysis free from its positivistic and Cartesian ties (Stolorow 2011). This article contributes to the same objective of connecting psychotherapy and Heidegger's philosophy. In contrast to Stolorow, we focus, not on Heidegger's Being and time, but rather on his late philosophy after the "turn". The concepts of paramount importance from this point of view are twofold thinking and Gelassenheit. Thus, we are continuing the project of Robert Stolorow, Medard Boss and Ludwig Binswanger in contextualising psychotherapy from Heidegger's philosophical standpoint. In bringing together psychotherapy and Heidegger's late philosophy, we also end up, at least to some extent, with contextualisations that differ from those of Stolorow. Our views on psychotherapy underline its mystical and antirationalistic underpinnings. 
There are three reasons for focusing on Heidegger's late philosophy. First, we are interested in finding out if his late philosophy could offer something more than or different to the philosophy of psychotherapy than his philosophy in Sein und Zeit. As far as we know, this has not been done earlier. Second, because we are interested in the mystical dimension of psychotherapy, Heidegger's later antirationalistic views seem promising to our project. In his late philosophy, Heidegger turned away from rational language. He started looking at literaure, lyrical poetry and his own highly idiosyncratic philosophy for ways of thinking about the human predicament. Third, although Heidegger did not elaborate his late philosophy until after the second world war, it can be interpreted as a reply to the philosophical dilemmas of the fin de siècle. To be more precise, in his late philosophy Heidegger tries to salvage a dimension lost after Kant's epistemological revolution. Thus it represents ideas and paradigms that were moulding the intellectual enviroment when psychotherapies began to emerge.

At the same time as recognising the importance of this kind of analysis, we have to admit that in the present intellectual and cultural situation such speculative thinking about psychotherapy has, at least to some extent, been lost and is considered as of no value in psychotherapy research. The change in emphasis becomes obvious if, for example, we compare the forewords to the first and second editions of the History of Psychotherapy (1992, 2010).

In 1992, Rollo May expressed concern that psychotherapy seemed about to lose its existential dimensions:

We have discovered that we also tend to lose our sensitivity and that we also face dangers similar to those faced by the AMA [American Medical Association] before us. There is a serious dilemma occuring in our vocation and in our practice of helping people with their personal problems. The question is, are we training technicians or professionals? (May 2011)

In the foreword 18 years later, the discourse has changed. Now, the emphasis is on empirical quantitative research and on psychotherapy as a part of medicine and as an intervention designed to treat various health issues across a multicultural population. Although Stanley Sue, in his foreword, considers the question, "What is psychotherapy?", the context has changed. Unfortunately, the suggested psychological or sociological answers fail to address the challenges that we are about to meet.

We are convinced that while the general understanding of psychotherapy has expanded enormously, something has also been lost. If we consider psychotherapy as an artefact with a mystical experiental nucleus, we see something other than what we see if we try merely to build theories for various subdomains of psychotherapy and investigate their interrelatedness. A mystical view leads us to ask what forms the experiential core of psychotherapy and how that core is related to its cultural background. We agree with Liran Razinsky (2016, 2017), who claims that psychoanalysis and, we would add, psychotherapies in general - has to strengthen its dialogue with the humanities. Doing so would benefit not only the humanities but also psychotherapies and psychotherapy research.

Furthermore, we would also like to see a revitalisation of transsendentalism in efforts to understand psychotherapy. It is promising that at the same time as rational constructions of psychotherapy have improved, something else has also been evolving. In 
classical psychoanalysis, this has meant a new interest in Jewish, or, more accurately, the kabbalistic and Hasidic roots of Freudian thought. Kabbalism and Hasidism are both mystical currents in Jewish thought. At the same time, relational psychotherapies have also incorporated mystical currents into their philosophical foundations. This, in turn, has led to an increased interest in Buddhist philosophy, transcendentalism and Heidegger's idiosyncratic philosophy We start with Martin Heidegger and his philosophy.

\section{Heidegger's philosophical mysticism and" Gelassenheit"}

Our starting point is the late philosophy of Martin Heidegger (1936)/2002, 1947/1978, 1957/1966) with special interest in his idea of twofold thinking and in his concept of gelassenheit. We interpret both psychotherapies and Heidegger's philosophy as being simultaneously a part of and a reaction to the sociocultural situation in Europe during the early 1900s. Both tried to escape from the intellectual dead end that formulations of the Kantian epistemological revolution had led to in the nineteenth century. Both tried to say something fundamental about human existence. The intellectual background to this situation was the secular interpretation of speculative mysticism (Weeks 1993) by Arthur Schopenhauer and Friedrich Nietzsche. The term refers to the imtellectual tradition that started with Plato and neoplatonism, and continued in the speculative mysticism of medieval times and Meister Eckhart up to Jacob Böhme, the romanicists and the antirationalists like Nietsche and Schopenhauer. Its most prominent belief is, that beside the rationally and linguistically understandable dimension of the world, there is something else, that cannotbecome understood through rational speculation. The most prominent and original fin de siecle philosophers, Martin Heidegger and Ludwig Wittgenstein, were familiar with Schopenhauer's thinking, as also was Sigmund Freud. As we will see, psychotherapy was, and remains, heavily influenced by this development in which mysticism and modernism were intertwined with each other.

Heidegger's philosophy is at the same time both concrete and highly theoretical. Paradoxes and neologisms make it difficult to understand. His unique way of using language, especially in his late philosophy, resembles the language that mystics use when they try to grasp and express something that is not expressible, at least not in propositional language. Generally speaking, it seems that philosophers who try to comprehend the borderland between the expressible and inexpressible create language that is beyond the scope of everyday language. In this article, we focus on three philosophers of this kind: Martin Heidegger, Sigmund Freud and Ludwig Wittgenstein.

In his speech Gelassenheit (Heidegger 1957/1966), Heidegger reflects on the legacy of the composer Konradin Kreutzer. He continues a project that he had already started in Being and time and analyses human existence. Or, more accurately, he invites us for a walk to encounter the mystery of being. Heidegger's late philosophy is far from the neutrality of traditional speculative and analytic philosophy.

Heidegger writes about the crisis of modern man that came about when he lost his ability to think, or at least became restricted to only one of the two modes of thinking, i.e., calculating thinking. This mode of thinking sets the world as its object and manipulates it according to its interests. It resembles Habermas's technical interest in 
knowledge and uses the world as raw material moulding it to fulfil its goals. In contrast, meditating thinking is open and slow, and it does not know where the thinking process will eventually lead. On top of that, meditating thinking does not define but patiently awaits what and how the world will reveal itself. Meditating thinking explicates the late Heideggerian understanding of truth as dialectic interplay between hiddenness and revelation. Meditating thinking does not aim at anything but waits openly at the door of being. (Heidegger 1957/1966).

Yet calculating thinking is not useless either. Heidegger does not, like Kierkegaard and Nietzsche, belong to the antirationalistic tradition. He values both modes, even if he considers meditating thinking more essential and original to human beings. If modern man forgets meditating thinking, he becomes severed from his roots and dehumanised. (Heidegger 1957/1966).

When seeking to explicate the nature of meditating thinking, Heidegger uses the word "Gelassenheit" and refers to Meister Eckhart, a theologian and mystic, who first coined this term. The reference to to Meister Eckhart is both interesting and complex. While it is true that Eckhart used the word "Gelassenheit", Heidegger did not use it to describe the same concept. The contents are not identical. Eckhart introduced the word "Gelassenheit" into the German language. The word means giving up and turning away from the world. The word has biblical roots in the Latin word "relinquere", which has a very concrete meaning, as in Matthew 4:20: "At illi continuo relictis retibus sunt eum" (At once they left their nets and followed him). "Relictis" comes from the verb "relinquere" meaning to relinquish or abandon. Eckhart ontologised the content of the word to mean turning away in a profound and existential way (Panzig 2005) in contrast to its concrete and practical original meaning.

Heidegger defines the word differently. To him, Gelassenheit refers to man's willingness to slowly become open to the world, without power or force, as it both presents and conceals itself. For Eckhart, Gelassenheit is a way of turning away from the world in order to be open to an encounter and union with God. The encounter between man and God, in which the act of God meets the intellect of man, is called Gescheidenheit. Gelassenheit is an act of the will whereas Gescheidenheit is an act of the intellect (Panzig 2005). In fact, roughly speaking, the concept of Gescheidenheit and the concept of Gelassenheit become fused in Heidegger's use of the word Gelassenheit. Although Heidegger's and Eckhart's ideas are conceptually different, their philosophical agendas are similar. Both use metaphorical language, create neologisms, expand the domain of language and seek to explain something essential about the human predicament.

A good example of this is found in Theologia Germanica. Although not by Eckhart, it is written in the Eckhartian mystical tradition. The metaphor of two eyes is at least an elegant exposition, if not antecedent, of Heidegger's theory of twofold thinking:

"But these two eyes of the soul of man cannot both perform their work at once; but if the soul shall see with the right eye into eternity, then the left eye must close itself and refrain from working and be as though it were dead."

Theologia Germanica, 20.

Surprisingly, the history of logic and its application to art history and understandng of cubism, invites a fresh look at the dualism mentioned above. It also shows that the idea 
of twofold thinking that Heidegger introduced was not only a philosophical theory. Above all, it was an explication of a general and basic intellectual dilemma in the beginning of the twentieth century.

Jean van Heijenoort (1967) pointed out that logic can be understood either as a calculus or as a universal medium. Logic as a calculus means that the relationship between logic and the world is transparent. Thus semantics is analysable. In contrast, logic as a universal medium means that the relationship is opaque and thus semantics is mute and not analysable. The Finnish philosopher Hintikka (1975a, b, 1981); Hintikka and Hintikka (1986) was one of the first to understand that the dichotomy has broad philosophical consequences. Applying Hintikka's interpretation, Martin Kusch and Jaakko Hintikka (1988) showed that Heidegger's late philosophy of language and the idea of meditating thinking are semantically based on the idea of language as a universal medium.

According to Hintikka (1975a, b), the contrast between traditional art and cubism illustrates the distinction. For example, one feature of cubism was that it tried to view its objects from different angles at the same time. The rationale was that it attempted to view reality as it is, not as it presents itself. So, cubism presents a radically different epistemological stance from that of Kantianism. It also differs from Heidehgger's idea of meditating thinking. Heidegger thought that there are dimensions in the world that are not rationally explicable but can become revealed through meditative thinking. In cubism the representational function is rationally explicable, and more than that, it can be varied. In contrast, traditional art had conceived this relation as self-evident and historically constant. Picasso's Portrait of Dora Maar (1937) makes this epistemological stance explicit:

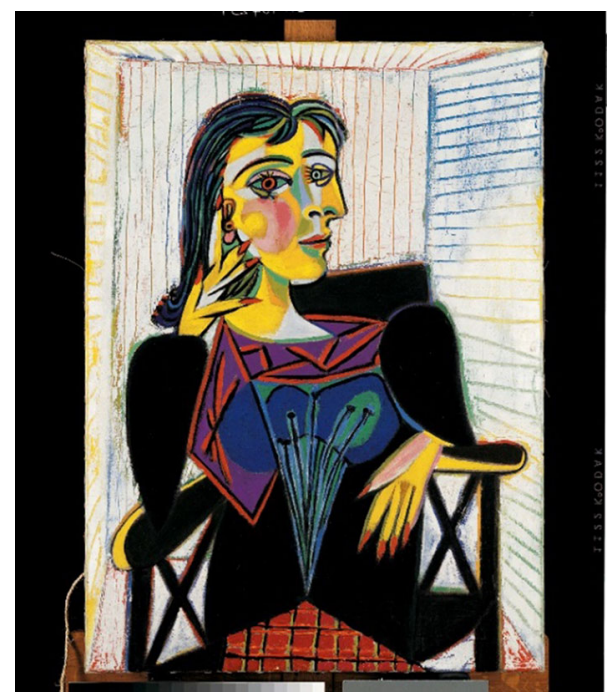

In the painting the face of Dora Maar is simultaneously perceived from two angles. Picasso seems to have tried to perceive his mistress as she was, not as she appeared. Hintikka (1975a, b) correctly pointed out that Friz Novotny's reading of modern art as "gemalte Erkentnisskritik" applies even more to cubism than to Cezanne. Novotny had interpreted Cezanne's way of fusing traditional perspectivism as an attempt to show that in reality the shapes in the painting in a way grow on the surface of the canvas. In other 
words, Cezanne had also been interested in the concrete reality of the painting, not only in mimicking an optical illusion (Blaha 2009). This contrast between reality and phenomenalism later evolved to become one of the typical characteristics of cubism.

The representational relationship between art and reality became emancipated from the straightjacket of Renaissance perspectivism. In contrast, Heidegger's meditating thinking is in line with the traditional understanding that the function of representation is constant and opaque. Calculating thinking, in turn, represents an epistemological stance that is transparent and contingent. It is exemplified in Cubism and also in atonal music (Schönberg, Webern, Berg), which changed the view of self-evident tonality and replaced it with the epistemologically transparent twelve-tone technique. Tonality became interpreted as a calculus. There was no natural, self-evident musical language. Instead music could be freely structured.

Both Cubism and atonal music are attempts to step out of the box, which is impossible from Heidegger's point of view; as family therapists in the 1980s used to say: only a fish doesn't understand that it is swimming in water. In a sense, Heidegger 's view was antithetical to modernism and represented a critical stance against the idea of a language as a calculus. Nevertheless, Heidegger did not, unlike Kant, claim that the domains of reality that are beyond the rational mind are totally unattainable. Meditating thinking captures, from Heidegger's point of view, domains that do not admit of rational specuöation.

Meditating thinking, by underlining the opaqueness of experience, opens up a new domain in the psychotherapy process. This dimension cannot become an object of calculating thinking. It can't becone an object of the rational eye. These areas of vague experience can only be opened up by meditating thinking. This domain is not necessarily transempirical per se. Neurological and somatic markers can be used in finding and pointing to moments or areas like these. For example, the research project Relational Mind (Lampinen et al. 2018, Paananen et al. 2018 etc), conducted at the University of Jyväskylä, has been pioneering this promising field of research. Notwithstanding, the innermost essence of the realm of meditative experiencing cannot be approached solely from the viewpoint of calculating thinking. Calculating thinking is useful in marking and indicating it, but its core remains hidden from rational speculation.

In addition to the modern integrative research projects and Heideggerian philosophical stance, more traditional empirical psychology and psychoanalysis have also tried to conceptualise the domains of the transrational and translinguistic. For example, Donald Winnicott's concepts of transitional space (Winnicott 1953) and the use of an object (Winnicott 1969), the ideas of the analytic third proposed by Thomas Ogden (1994) and Benjamin (2018), Lev Vygotsky's theory of the zone of proximal development (Vygotsky 1978) and the importance of uttering not-yet-said thoughts in the dialogical therapies (Seikkula and Trimble 2005) are all attempts to grasp something of this phenomenon of becoming. In other words, the concepts listed above seek to grasp something that is not yet here and now, but which is in the process of evolving. These concepts nevertheless refer to other domains than Heidegger's.

The focus in the above-mentioned concepts has on the process of actualising the not yet existent. Thus, the question has generally been "How does human experience become transformed from the domain of meditating thinking to that of calculating thinking?" From the Heideggerian point of view this is a mistake. This approach seems to entail the idea that the potential or not yet existent cannot as such become an object of thinking. Moreover, the interest shown by this tradition in the idea of evolving 
denotes a belief that it is the process of becoming rationally explicable that is interesting, and not the domain of meditative thinking as such.

Heidegger flatly rejects this conclusion. He claims that meditating thinking can include itself to the potential and inexpressible. In his lecture Der Satzt vom Grund (1957), Heidegger interprets the famous saying of Wilhelm Leibniz, Nihil est sine ratio. Heidegger points out that the word ratio has two different etymological roots. On the one hand it stems from the Latin word reor that has echoes in the German language, for example in the words "rechen"(to calulate) and "rechende" (calculating), while on the other hand it is a translation of the Greek word logos. Logos in turn stems from verb legein (to say, to speak) and at the same time refers to the ultimate basis of reality in both Christianity and Neoplatonism. If psychotherapy is considered from this standpoint, it seems that, apart from the process of actualisation, an important part of psychotherapy also relates to the so-called nonexistent, or more accurately, to the ultimate basis of existence, which cannot be apprehended by calculating thinking. Later, Ludwig Wittgenstein referred to the same dilemma when he said that the meaning of the world cannot be found in the world (meaning the verbally understandable world). It must come from outside (Wittgenstein 1921/1974, 6.41). For Wittgenstein outside means inaccessible to language and rational thought. Hence, Wittgenstein can be understood as thinking along the same lines as Heidegger few decades later. Both are representatives of the tradition of speculative mysticism.

\section{Rationalty, language and beyond}

Two other contemporaries of Heidegger have also been interested in the same zone between immanence and transcendence: Sigmund Freud and Ludwig Wittgenstein. Both attempted to solve the question of whether knowledge about ultimate reality is rationally attainable or not.

Heidegger (1927/1962) states already in Being and time that the human way of being in the world is impregnated with practicality. We do not perceive objects as such, that is, how they are independently. Thus far, Heidegger accepts Kant's epistemology. But in contrast to Kant, Heidegger concludes that the only way we as humans can relate to the world is through our various practical down-to-earth activities: it is these that determine how we perceive the world. It seems that Heidegger subsequently moved away from this only partially Kantian idea. He explicitly says that his philosophy changed after Being and time. Heidegger (1947) names this change the "turn" (Die Kehre).

In the present context of psycotherapy, it is is useful to interpret Heidegger's turn as an attempt to revive the question about the relationship between human intellect and ultimate reality. Heidegger seemed to have brought noumena back into the human situation. In so doing, he gradually lost reliance on the ability of propositional language to understand whole reality and its dimensions. Like his alter ego, the poet Hölderlin, he tried to find a suitable language and form of expression to articulate human experience at its most profound level. He turned more and more to the language of art and poetry, where he found, at least to some extent, what he was looking for (Heidegger 1936/2002).

On one hand, Heidegger was a heir of the antirationalistic tradition that started with Romanticism and continued with Kierkegaard, Nietzsche and Schopenhauer towards the end of he century. Heidegger gave up conceptual language as a means to explore 
ultimate reality. However, he did not abandon rational thinking altogether. It continued to have a place in the area of calculating thinking. In a way, Heidegger followed Augustine, who, in his De Civitate Dei, believed that the phenomenal world comprised two worlds intertwined together. He called them civitate dei and civitate terrene (Augustine 1980). Augstine's politico-theological pamphlet and attempt to integrate the Greek and Roman cultural traditions with Christianity. It invoked the idea that the world consists of two dimensions - the rationalistic and the mystical - that are inseparable and dependent on each other.

Heidegger's philosophy, sharing Augustine's basic view, played an important role in the rich cultural situation that prevailed in Europe in the first half of the twentieth century. At the same time, psychoanalysis, expressive art, atonal music, modern logic, relativity theory and quantum mechanics were all part of European culture. In pictorial art, the cubists refused to accept the traditional view of how art was supposed to represent reality, and Marxist movements questioned existing socio-political structures. The crisis of representational function and revolutionary political movements fertilised each other and new ideas and modes of thought arose. Questions about certainty and representation started a process that led to new ways of approaching the dilemma of the world as mundus rationalis and as mundus reconditus. Analytic philosophy and logical empiricism emerged (Jones 1975). Although, later, Heidegger and analytic philosophy drifted apart as representatives of contradictory philosophical positions, both positions had roots in the same intellectual soil. And that same soil was also fertilising psychotherapy, its origin and development.

\section{Linguistic turn}

The result of this process was called the linguistic turn. It was a critique levelled against the constructivistic epistemology that was dominant in the late nineteenth century. Immanuel Kant had started a development leading to a relativistic epistemology that understood the phenomenal world as a product moulded by the human intellect. Although in Kant's original view the world as such (das Ding an sich) was preserved, the concept had more or less disappeared from epistemological speculation by the late nineteenth century. Descartes had sought to prove that knowledge of the external world is possible. Kant and subsequent thinkers, at least temporarily, demolished the Cartesian dream.

Gottlob Frege wanted to restore the idea of objective reality in philosophy. However, as a mathematician, he approached it in a different way. First, like Plato, he considered mathematical objects to be non-phenomenal entities that exist in the external world. And secondly, he considered the laws of mathematics and logic to be the laws of the real world. Thus, Frege thought that because the invariant laws of logic are valid in objective reality, this solved the puzzle of constructivism. The laws of thought are also laws of reality. The world as an object of knowledge consists of atomic sentences. Logic is a science that explains the relationships between these modular entities. The world as a meanngful entity and the laws of mathematics and logic became identified. The antirationalist movement in philosophy and also the transempirical aspects of psychotherapy became labelled as nonsense. 
Ludwig Wittgenstein (1917/1974) continued this linguistic revolution launched by Frege and Bertrand Russell. However, Wittgenstein's Tractatus contains an important amendment. Wittgenstein shared the idea that a meaningful linguistic expression consists of elementary perceptual sentences and of logical form. Only sentences structured like this are meaningful. But language does not account for the whole of reality. Something else, that manifests itself otherwise exists outside language. This something can be called mystical. In contrast to later logical empiricism, this something is not nonsense but instead something important and valuable. In a sense, both Wittgenstein and Heidegger - and psychotherapy too seek to point to the territory beyond that which is linguistically meaningful. While Wittgenstein is content to state that the mystical manifests itself otherwise, Heidegger looks to art and poetry in trying to gain a hold on the propositionally inexplicable.

\section{Freud the rationalist, Freud the mystic}

Yet another Viennese, Sigmund Freud, tried to understand reality and its meaningfulness. Specifically, he was interested in what terms symptoms of hysteria and dreams could be understood as logical/meaningful (Freud and Breuer 1894; Freud 1900). The theory that he came up with, however, was also part of the linguistic turn. According to Freud, the obscure logic of dreams conceals their true meaning. This meaning can be revealed, and thus dreams thoughts understood, if the dream text is decoded. The dream is par excellence a text in which logic is blurred and obscure. When the logical form of the dream is clarified, its content will be seen as logically fulfilling the dreamer's desires.

Thus, it becomes obvious why the early logical empiricists saw psychoanalysis as heralding a new dawn in the social sciences (Uebel 2007). In some way, Freud was drawing on Russell's logical analysis (e.g. Russell 1905) in interpreting dreams. While this was not, of course, a conscious effort, both Russell and Freud played a part in the same cultural and intellectual revolution. Russell and Freud were both realists and rationalists. Thus, it is understandable that the early Freud took a different path from that of Heidegger and Wittgenstein. His path did not lead beyond the rationally explicable. Although Freud's trust in a heroic intellect and heroic psychoanalyst faded, he did not abandon his trust in rational thinking. This is clear in his discussion with the poet and mystic Rainer Maria Rilke. Freud prefered to bow his head before the goddess Necessitas than turn towards the mystical. In his New Lectures on Psychoanalysis Freud (1933/1961) was already comparing science and religion - and he chose science. He was, above all, a scientific realist.

There is no doubt that Freud would have respected the" holy oath" of the Physiological Society of Berlin. Emil du Bois-Reymond wrote in 1842:

"Brücke and I pledged a solemn oath to put into effect this truth: No other forces than the common physical-chemical ones that are active within the organism. In those cases which cannot at the time be explained by these forces one has either to find the specific way or form of their action by means of the physiomathematical method, or to assume new forces equal in dignity to the physical- 
chemical forces inherent in matter, reducible to the force of attraction and repulsion."

Holt 1968, 202.

Freud also wanted to base his new science on mechanical physiology and neurology. He never gave up his scientific program (Entwurf) for psychology (Freud 1895). Psychoanalysis was to be assimilated into materialistic science.

It is for this reason that Freud would probably have been delighted to witness psychonalysis and the cognitive sciences sharing common ground a hundred years later. Freud believed in his project and could relate to mysticism only by reducing it in the same way as his admired teacher Ludwig Feuerbach had done (Gay 1989). In the Psychopathology of Everyday Life (1901), he wrote:

...in the construction of a supernatural reality, which is destined to be changed back once more by science into the psychology of the unconscious. One could venture to explain in this way the myths of paradise and hell, the fall of man, of God, of good and evil, of immortality, and so on, and to transform metaphysics into metapsychology.

Freud 1901, 258.

In his letter of 26 August 1919 to his friend and colleague Lou Andreas Salome, he vividly expresses his uneasiness reading Schopenhauer's antirationalistic philosophy:

"Ich habe mir jetz als Altenteil das Thema des Todes ausgewählt, bin uber ein merkwurdige Idee von den Trieben aus gestolpiert und muss jetz allerlei lesen, was dazu hört, z.B. zum ersten mal Schopenhauer. Ich lese aber nicht gerne. [and I have to read anything that it entails. For example, for the first time, Schopenhauer. I don't do it with pleasure.]"

Freud, S. \& Salome, L.A. 1980, 109.

It is interesting that both Wittgenstein and Freud knew Schopenhauer and his concept of the metaphysical will. In fact, as Magee, von Wright and Malcolm have pointed out (Magee 1983), Schopenhauer was, for Wittgenstein, one of the most influential philosophers. He drew on Schopenhauer's mysticism and Kantianism in his own idiosyncratic thiunking. Freud, too, started to read Schopenhauer when he tried to conceptualise the theory of the death instinct. In contrast to Wittgenstein, Freud, as a rationalist, had obvious difficulties in reading Schopenhauer.

Neverthelss, Freud was also a mystic. He was both a rationalist and non-rationalist. In the end, it can be questioned whether Freud carried out his early programme in practice. It seems that he did not. And on top of that, there is also the question about Freud as a Jew. He saw himself as a godless Jew. Yet in many contexts, such as in his letters to his wife Martha and Romain Rolland, Freud saw himself as a cultural Jew. It has often been pointed out that striking similarities exist between Freud's psychoanalysis and Jewish mysticism, especially kabbalism and Hasidism. Kabbalism was described in literary form in the twelfth century but its history was intertwined with that of neoplatonism in the third century. Neoplatonism and kabbalism share, for example, the same understanding of creation through emanative processes (Jones 1970; Starr 2008). 
Kabbalism started as a movement aiming at reforming Jewdaism. The kabbalists wanted to do away with what they saw as a stagnated spirituality and revitalise the life-form informing Judaism at that time. However, from its very beginnings, kabbalism had another, more personal layer. It also aimed at helping people to transform and renew their personal being. The concept tikkun ha-lev, restoration of the heart, points to this objective. It refers to finding one's authentic self, to becoming whole again through the process of repentence, atonement and sorrow. The poet and kabbalist Pinchas Sadeh illustrates the process as he felt it:

...time, fate, life and death - all these powerful forces prevent the possibility of repairing that which is broken. If so, what is possible? What remains for a man to do, after all? What can save and rescue the things that are smashed? Maybe only - and even this only through tremendous effort, through difficult struggle, through great pain - this; repairing the heart. In other words, repairing the heart, which was broken when all those things were broken. (Berke 1996).

Although psychoanalysis and Jewish mysticism share many views on both the content and process levels, it can be questioned whether Freud really was influenced by kabbalism. It is well known that Freud both cultivated the spirit of enlightment throughout his life and renounced religion. His explicit Weltanschauung was a scientific one (Freud 1933), even if Freud was a Jew, his closest friends and the first scientific audience were Jewish, and his family stemmed from Hasidic roots in Galicia, which was saturated with Jewish mysticism, as described by David Bakan (Bakan 1958; Berke 1996). We should also mention, that it was in Galicia that Ludwig Wittgenstein had one of his mystical experiences (McGuinnes 2005).

Freud had many books on Judaism on his book shelves (Bakan 1958) and he also owned the Zohar, which is a kabbalistic book offering mystical interpretations of the Torah. He also told Hasidic stories to his patients, when he wanted to make a point. At the same time Freud sought to diminish Jewish influence on his theories, partly because he did not. Want to be subjected to antisemism, and partly because he was an heir of the enlightment and natural scientific progress in the last half of the nineteenth century.

It can hardly be a coincidence either that he decided to die on Yom Kippur, which is the last of the ten days of repentence that start at Rosh Hashanah, the Jewish New Year. During Yom Kippur, every Jew has an opportunity to repent and start over again. Doctor Max Schur assisted Freud in his death (Gay 1989; Schur 1972). Thus, Freud deliberately chose the day he was ready to die. In so doing, he can argued to have made a covenant with his past as a Hasidic Jew and made atonement with his life. In the Hasidic Jewish tradition, Yom Kippur was an especially favourable day to die and leave this world (Berke 2015). It was partly owing to Freud's Jewishness and partly to Schopenhauer and Nietzsche that the tradition of mysticism found its way into Freud's rationalistic mind.

The contradictory aspects of Freud's legacy continue to mould psychotherapeutic thinking and psychotherapy research. While psychoanalysis has been decried by some as nonsense or pseudoscience, the hermeneutic tradition and critical theory at least have adopted psychoanalysis and cited it as an example par excellence of a scientific attitude. In the same way, evaluations in psychotherapy research have varied from dismissal to high regard. These contradictory 
views on Freud are not informative only about him. Instead, both Freud and evaluations of him have been evolving in the intellectual soil, that has been fertilised by both positivism and mysticism.

Both the contradictions in Freud's thought and contradictory evaluations of his thought show how the intellectual dilemmas of the fin de siecle have influenced both Freud and the development of psychotherapy in general. Often, in conversations about the essence of psychotherapy, the importance of the mystic and antirationalistic underpinnings in the development of European thought around the beginning of the twentieth century have been neglected, as also have the importance in the development of psychotherapies. Psychotherapy has inherited the ambivalence concerning positivism and mysticism.

\section{Psychotherapies and the so-called mystical}

The so-called mystical has been a part of the psychotherapeutic endeavour in three ways. First, Freud's psychoanalysis was influenced by Jewish kabbala mysticism and Hasidism. Second, from the philosophical point of view, psychotherapy, or at least an important part of it, has grown in soil fertilised by speculative mysticism from Platon to Wittgenstein. Third, from the historical and empirical points of view, psychotherapy is the heir both of ancient healing ceremonies and of modern science. This becomes obvious if we consider the ideas of, among others, Fromm and Suzuki (1960), Wilfred Bion (Cooper 2018), Alan Watts (1961) and Takeo Doi (1973) for whom western psychotherapy and the Asian spiritual heritage are parts of the same picture. In psychotherapy, interest in the orient and its philosophy and healing practices started in the 1930s, when C.G. Jung wrote a commentary on the Chinese text The Secret of the Golden Flower that was published in English in 1936. Thus interest in Asian spirituality among Western psychotherapists was aroused long before the third wave of cognitive therapies popularised mindfulness and Buddhism in western medical thinking. A few decades later Alan Watts combined Buddhism with western psychology in his book Psychotherapy East and West and Takeo Doi researched dependency and independence in Japanese amae spirituality. The psychoanalytic philosophy of Wilfred Bion is also influenced by Indian religious thinking. Buddhist philosophy has also become more and more popular recently in relational psychoanalysis. For example, discussion on this topic was actively initiated by the Buddhist psychoanalyst Safran (2003). The ancient roots of psychotherapies are again visible in conversations about psychotherapy.

At the same time the ancient roots of psychotherapy has also been revived in another way. Since the beginning of the twenty-first century there have been further attempts to place spirituality and psychotherapy in the same picture (Post and Wade 2009). It is well known that the relationship between psychotherapy and spirituality has been an issue from the very beginning of psychotherapies. In addition to the mystical tradition in which Freud grew up, the correspondence between Freud and Oscar Pfister and Freud and Romain Rolland make this obvious (Berke 2015; Freud and Pfister 2013). We interpret this as being at least indirect proof that psychotherapy is not solely a medical treatment. Psychotherapy has also its phiolosophical, antirationalistic and mystic underpinnings. 
Because, historically, psychotherapy evolved from premodern healing practices, it is also connected in its practice to the most profound, transcendent dimension of human existence. This dimension is easily neglected or forgotten, if psychotherapy is interpreted only in a rational objectifying way, as in Heidegger's calculating thinking. We would like to preserve the larger area of the inexplicable as a legitimate part of psychotherapy. Following Heidegger's terminology, we want to preserve the ultimate ground of being as a dimension also in modern psychotherapies. We are convinced that a profound understanding of psychotherapy presupposes that we also take into account the so-called mystical layers of psychotherapy that stem from its sometimes forgotten roots in the intellectual atmosphere of the fin de siècle.

It seems, then, that if we borrow the insurance specialist Reinhard A. Hohaus's famous analogy of a three-legged-chair (used frequently in evidence-based medicine), psychotherapy as a totality is like a chair with three legs: one leg is psychotherapy as a part of modern medicine; another leg is psychotherapy as a social healing practice with its premodern roots; and the last leg is psychotherapy as an application based on a philosophical stance aimed at meaning-generating processes. It seems obvious to us that all three legs have not developed evenly. The medical leg has grown the most. The social healing leg has been a focus for both systemic family therapies and the contextual paradigm of psychotherapy proposed by Bruce Wampold and Zac E. Imel. The last leg - the philosophical, existential, humanistic or mystic leg - has been starved. It flourished briefly after the second world war and during the the flower power era of the 1960s, but has since declined in importance (Wampold and Imel 2015; Rice and Greenberg 1992). The medical aspect of psychotherapy naturally underlines the importance of rational control. So, the other legs that tend to enhance vagueness and plurality are easily neglected. Wampold (2012) has tried to re-establish the importance of the last leg with his claim that the general factor common to psychotherapies is humanism.

We contend, however, that the last leg of the chair consists of the tradition of speculative mysticism in the secular form that it took around the beginning of the twentieth century, especially in the philosophies of Wittgenstein and Heidegger. This last leg is elegantly articulated in Wittgenstein's Tractatus (6.43): "The world of the happy individual is a different one from the one of the unhappy individual". The world consists of something that is rationally explicable and also of something that cannot be uttered in language. It is something (Das Mystische) that shows itself otherwise, as Wittgenstein said, or something that can become known only through meditative thinking, as Heidegger might have have said.

The relationship between the so-called mystical and rational in psychotherapy can be conceptualised in different ways. First, the mystical can become reduced to rationality. This is basically a Freudian alternative. Second, it can be claimed that research based on calculating thinking is the best way to understand the essence of psychotherapy. What this point of view leaves out is considered either not crucial or not significant or even meaningless. Third, both aspects can be considered as necessary aspects of psychotherapy. In the Heideggerian philosophy, choosing between alternatives is not expected. Rather, psychotherapy and psychotherapy research should include elements from both modes of thought. However, as Heidegger reminds us, meditating thinking needs to be considered the primary mode. 
We claim that if we fail to take into account the mystical dimension, we lose an irreplaceable aspect or standpoint from which to view the philosophy of psychotherapy. Moreover, we lose a necessary perspective on the subjective experience of the individual when we consider the "moment of meeting", as Daniel Stern puts it, that takes place in psychotherapies. An understanding of the mystical layers in psychotherapies is needed to capture and conceptualise the meaningful dialogical exchanges that occur in psychotherapeutic conversations. Thus, to fully conceptualise psychotherapies and to carry out even better and more comprehensive research, empirical psychotherapy research needs an understanding of the antirationalistic and mystical dimensions of psychotherapies and psychotherapeutic encounters. In other words, psychotherapy research needs philosophical research.

We would like to see more empirical psychotherapy research projects focusing on subjective experiences in psychotherapies. Economic factors and the medical paradigm has led to a situation in which quantative research in general and effectivity research in particular have become major trends in psychotherapy research. As a result, we know quite a lot about the effectiveness and efficacy of psychotherapy, but surprisingly little about patients' and therapists' subjective experiences of being in the siuation called psychotherapy.

\section{Conclusions}

From time to time it is important to reprise the question "“'What is psychotherapy?" The question cannot be answered by referring to specific psychotherapies alone, to outcome studies, to psychotherapeutic discursive processes or to somato-neurological aspects of psychotherapy. Psychotherapy is also essentially a cultural project and as such an artefact with humanistic dimensions. We are not seeking to undermine empirical research, but instead we underline the importance of the largely neglected sociocultural, basically philosophical, dimension of psychotherapy and psychotherapy research. As a part of this project, it is utterly important, if we want to understand the inner nature of psychotherapy, that we do not neglect the intellectual heritage of the fin de siecle, with its rational and mystic underpinnings.

It is obvious, as we see it, that philosophical issues have been present in psychotherapy from the very beginning, They are not something added on. Instead, philosophy has played an important role continuously as well as in the formative years of modern psychotherapies. This means that psychotherapy cannot be properly understood without due consideration to its philosophical background. In this respect, psychotherapeutic traditions differ from each other. A vast amount of research on psychoanalysis and its historical, philosophical and sociological origins has been carried out. Research has not examined other therapies in the same way or in comparable depth.

We believe we have been able to show that although it is crucial to study the philosophy of psychotherapies from specific and narrowly focused viewpoints, it is also of interest to view psychotherapies from larger philosophical perspectives. The history of ideas and intellectual history are also part of psychotherapy research. For example, we found that the tradition of speculative mysticism helps to understand certain aspects of modern psychotherapies. We also feel that Heidegger's idea of twofold thinking along with Heijenoort's twofold understanding of logic either as calculus or as language 
elegantly illustrates this tradition and provides conceptual tools with which to analyse psychotherapy and its history. It is well known, that psychotherapy has been evaluated in accordance with Heidegger's philosophy in Being and time. This was first done by Ludwig Binswanger and Medard Boss, and then by Robert Stolorow. We have shown, we believe, that Heidegger's late philosophy opens up new horizons that are useful in understanding dimensions in the psychotheraputic encounter that are difficult to grasp in any other way. Lately this domain of psychotherapy has been elaborated specially in relational psychotherapies, for example in relational psychoanalysis.

Funding Information Open access funding provided by University of Jyväskylä (JYU).

\section{Compliance with Ethical Standards}

Conflict of Interest The authors declare that there are no potential conflicts of interest in this article.

Humans and Animal Studies Since the article is purely a theoretical, there are no participants, humans or animals, whose rights might have been violated. So, no consent was needed.

Open Access This article is distributed under the terms of the Creative Commons Attribution 4.0 International License (http://creativecommons.org/licenses/by/4.0/), which permits unrestricted use, distribution, and reproduction in any medium, provided you give appropriate credit to the original author(s) and the source, provide a link to the Creative Commons license, and indicate if changes were made.

\section{References}

Augustine. (1980). The city of God. Harmondsworth: Penguin Books.

Bakan, D. (1958). Sigmund Freud and the Jewish mystical tradition. London: Free Association Books.

Benjamin, J. (2018). Beyond doer and done to. Recognition theory, intersubjectivity and the third. London: Routledge.

Berke, J. H. (1996). Psychoanalysis and kabbalah. The Psychoanalytic Review, 83(6), 849-863.

Berke, J. H. (2015). The hidden Freud. His Hasidic roots. London: Taylor \& Francis Ltd..

Blaha, A. (2009). Fritz Novotny and the new Vienna school of art history - An ambiguous relation. Journal of Art Historiography, 1(December), 1-13.

Cooper, P. S. (2018). Zen insight, psychoanalytic action: Two arrows meeting: Relational perspectives. New York: Routledge.

Doi, T. (1973). The anatomy of dependence. Tokyo: Kodansha International.

Enckell, H., \& Enckell, M. (2013). The companion to the unknown. With the question as a starting-point and the mystery as a destination? The Scandinavian Psychoanalytic Review, 36(1), 5-11.

Freud, S. (1900/1961). The interpretation of dreams. Standard edition 4-5. London: The Hogarth Press and The Institute of Psychoanalysis.

Freud, S. (1901/1961). The pathology of everyday life. Standard edition 6. London: The Hogarth Press and The Institute of Psychoanalysis.

Freud, S. (1933/1961). New introductory lectures on psychoanalysis. Standard edition, 22. London: The Hogarth Press and The Institute of Psychoanalysis.

Freud, S. (1960). In E. L. Freud (Ed.), Letters of Sigmund Freud. New York: Dover Publication INC..

Freud, S. (1895). Entwurf einer Psychologie. Gesammelte Werke. Nachtragsband.

Freud, S. \& Andreas-Salome, L. (1980). Briefwechsel. Frankfurt am Main: S.Fischer-Verlag.

Freud, S., \& Breuer, J. (1894). Studies on hysteria. Standard edition 1. London: The Hogarth Press and The Institute of Psychoanalysis.

Freud, S., \& Pfister, O. (2013). Briefwechsel 1909-2013. Zürich: Theologischer Verlag Zürich. 
Fromm, E., \& Suzuki, D. T. (1960). Zen Buddhism and psychoanalysis. New York: Harper \& Row.

Gay, P. (1989). Freud. A life for our time. New York: WW Norton \& Co..

Heidegger, M. (1927/1962). Being and time. New York: Harper \& Row.

Heidegger (1936/2002). The origin of the work of art. Off the beaten track. Ed. Young, J., Haynes, K. Cambridge: Cambridge University Press.

Heidegger, M. (1947/1978). Letter on humanism. Basic writings: Nine key essays, plus the introduction to being and time. London: Routledge.

Heidegger (1957/1966). Discourse on thinking. New York: Harper \& Row.

Heijenoort, J. (1967). Logic as calculus and logic as language. Synthese, 17, 324-330.

Hintikka, J. (1975a). Intenoions of intentionality. Dodrecht, Boston: D.Reidel. Synthese Library, 90.

Hintikka, J. (1975b). Conception as vision: On the problem of representation in modern art and in modern philosophy. Rudolf Carnap, logical empiricist. Ed. Hintikka J., pp.217-242. Dodrecht: Springer.

Hintikka J. (1981), Wittgenstein's semantical Kantianism. Ethics. Proceedings of the fifth Wittgenstein symposium. Ed. Morscher, E., Stranzinger R. Hölder- Vienna: Pichler-Tempsky,

Hintikka, J., \& Hintikka, M. B. (1986). Investigating Wittgenstein. Oxford: John Wiley and Sons Ltd.

Holt, R.R. (1968). Beyond vitalism and mechanism: Freud's concept of psychic energy. Historical roots of contemporary psychology. Ed. Wolman, B.B., 196-226. New York, Evanston, London: Harper \& Row Publishers.

James, W. (1902/2010). Varieties of religious experience: A study in human nature. Being the Gifford lectures on natural religion delivered at Edinburgh in 1901-1902. London: Longmans, Greens and Co.

Jones, W. T. (1970). A history of western philosophy. The classical mind. New York: Harcourt Brace Jovanovich Inc..

Jones, W. T. (1975). A history of western philosophy. The twentieth century to Wittgenstein and Sartre. New York: Harcourt Brace Jovanovich Inc..

Kandel, E. (2012). The age of insight. The quest to understand the unconscious in art mind and brain, from Vienna 1900 to the present. NewYork: Random House.

Kusch, M., \& Hintikka, J. (1988). Kieli ja maailma. Pohjoinen.

Lampinen, E., Karolaakso, T., Karvonen, A., Kaartinen, J., Kykyri, V., Seikkula, J., \& Penttonen, M. (2018). Electrodermal activity, respiratory sinus arrhythmia and heart rate variability in a relationship enrichment program. Mindfulness, 4, 1076-1087.

Magee, B (1983). The philosophy of Schopenhauer. Oxford Scholarship Online. November 2003.

May, R. (2011). Abbreviated foreword to the first edition. In J. C. Norcross, G. R. Vandenbos, \& D. K. Freedheim (Eds.), History of psychotherapy. Continuity and change. Washington, DC: American Psychological Association.

McGuinness, B. (1988/2005). Young Ludwig. Wittgenstein's life 1889-1921. Oxford: Oxford University Press.

Ogden, T. (1994). The analytic third: Working with intersubjective clinical facts. The International Journal of Psychoanalysis, 75, 3-19.

Paananen, K., Vaununmaa, R., Holma, J., Karvonen, A., Kykyri V., Tsatshisvili, V., ... Seikkula, J. (2018) Electrodermal activity in couple therapy for intimate partner violence. Contemporary Family Therapy, 40, $138-152$.

Panzig, E. A. (2005). Gelazenheit und abegescheidenheit. Eine einfuhrung in das theologische denken des meister Echart. Leipzig: Evangelische verlagsanstallt.

Post, B. C., \& Wade, N. G. (2009). Religion and spirituality in psychotherapy: A practice friendly review of research. Journal of Clinical Psychology, 65(2), 131-146.

Razinsky, L. (2016). On the need for openness to the humanities in psychoanalysis. Psychoanalytic Psychology, 33, 556-574. https://doi.org/10.1037/pap0000064.

Razinsky, L. (2017). Psychoanalysis and postmodernism. A response to Dr. Jon Mill's "challenging relational psychoanalysis: A critique of postmodernism and analyst self-disclosure". Psychoanalytic Perspectives, 14(3), 356-363.

Rice, L. N., \& Greenberg, L. (1992). Humanistic approaches to psychotherapy. In D. K. Freedheim (Ed.), History of psychotherapy: A century of change (pp. 197-224). Washington, DC: American Psychological Association.

Russell, B. (1905/1997). On denoting. Mind. New Series, Vol.14, No.56 (Oct.), 479-493.

Safran, J. (2003). Buddhism and psychoanalysis. An unfolding dialogue. Boston: Wisdom Publications.

Schorske, C. E. (1961/1981). Fin-de-siécle Vienna. Politics and culture. New York: Vintage Books. A division of random house.

Schur, M. (1972). Freud: On living and dying. New York: International University Press.

Seikkula, J., \& Trimble, P. (2005). Healing elements of therapeutic conversation: Dialogue as an embodiment of love. Family Process, 44(4), 461-475. 
Starr, K. (2008). Repair of the soul: Metaphors of transformation in Jewish mysticism and psychoanalysis. New York: Routledge.

Stern, D. (1998). Non-interpretative mechanisms in psychoanalytic therapy: The something more than interpretation. The International Journal of Psychoanalysis, 79, 908-921.

Stolorow, R. (2011). World, affectivity, trauma. Psychoanalytic inquiry book series Vol 35. New York: Routledge.

Uebel, T. (2007). Philosophy of social science in early logical empiricism. Teoksessa A. Richardson \& T. Uebel (toim.), The Cambridge companion to logical empiricism (s. 250-277). New York: Cambridge University Press.

Vygotsky, L. S. (1978). Mind in society: The development of higher psychological processes. Cambridge: Harvard University Press.

Wampold, B. (2012). Humanism as a common factor in psychotherapy. Psychotherapy., 49(4), 445-449.

Wampold, B. E., \& Imel, Z. E. (2015). The great psychotherapy debate. The evidence for what makes psychotherapy work (Second ed.). New York: Routledge.

Watts, A. (1961). Psychotherapy, east and west. New York: Pantheon Books.

Weeks, A. (1993). German mysticism from Hildegard of Bingen to Ludwig Wittgenstein. A literary and intellectual history. New York: State University of New York Press.

Winnicott, D. W. (1953). Transitional objects and transitional phenomena. International Journal of Psychoanalysis, 34, 89-97.

Winnicott, D. W. (1969). The use of an object. The International Journal of Psychoanalysis, 50, 711-716.

Wittgenstein, L. (1921/1974). Tractatus Logico-Philosophicus. London: Routledge \& Kegan Paul.

Publisher's Note Springer Nature remains neutral with regard to jurisdictional claims in published maps and institutional affiliations. 